\title{
The challenges of teamwork in the family health strategy
}

\author{
Os desafios de se trabalhar em equipe na estratégia saúde da família \\ Los desafíos de trabajar en equipo en la estrategia salud de la familia
}

\section{Hellen Emília Peruzzo ${ }^{1}(0)$ \\ Aline Gabriela Bega ${ }^{1}$ (C)}

Ana Patrícia Araújo Torquato Lopes ${ }^{1}$

Maria do Carmo Fernandez Lourenço

Haddad $^{2}$

Aida Maris Peres ${ }^{3}$

Sonia Silva Marcon ${ }^{1}$ (iD)

1. Universidade Estadual de Maringá.

Maringá, PR, Brasil.

2. Universidade Estadual de Londrina.

Londrina, PR, Brasil.

3. Universidade Federal do Paraná. Curitiba,

PR, Brasil.
Corresponding author:

Hellen Emília peruzzo.

E-mail: hellen_peruzzo@hotmail.com

Submitted on 12/05/2017.

Accepted on 06/25/2018.

DOI: 10.1590/2177-9465-EAN-2017-0372

\begin{abstract}
Objective: To grasp the perceptions and experiences of professionals in the primary health care as teamwork in the Family Health Strategy (FHS) in a medium-sized municipality in the southern of Brazil. Method: Qualitative research carried out, between April and July 2016, with 13 health professionals (nurses, doctors, dentists, community health agents, nursing technicians and oral health aide) workers in FHS. Data were collected through semi-structured interviews, transcribed and submitted to content analysis. Results: From the analysis emerged three thematic categories: Teamwork from the perspective of the FHS health professionals; Strategies for maintaining teamwork out of daily routine; and Challenges of the insertion of Oral Health in the FHS. Conclusions and implications for a practice: Participants demonstrated that they understood the importance of teamwork and interpersonal relationships, and recognize the inherent challenges of this process. They revealed weaknesses in the relationships among dentistry and other members of the FHS, marked by a sense of exclusion and disinterest in participating.
\end{abstract}

Keywords: Patient Care Team; Family Health Strategy; Health Personnel.

\section{Resumo}

Objetivo: Apreender as percepções e vivências dos profissionais quanto ao trabalho em equipe na Estratégia Saúde da Família (ESF) em um município de médio porte no Sul do Brasil. Método: Pesquisa qualitativa, realizada entre abril e julho de 2016 com 13 profissionais (enfermeiros, médicos, dentistas, agentes comunitários de saúde, técnicos de enfermagem e auxiliar de saúde bucal) atuantes em equipes da ESF. Os dados foram coletados por meio de entrevistas semiestruturadas, posteriormente transcritas e submetidas à Análise de Conteúdo. Resultados: $D a$ análise emergiram três categorias temáticas: $O$ trabalho em equipe na perspectiva dos profissionais da ESF; Estratégias para a manutenção do trabalho em equipe no cotidiano; e Percalços da inserção da Saúde Bucal na ESF. Conclusão e implicações para a prática: Os participantes demostraram perceber a importância do trabalho em equipe e do relacionamento interpessoal, e reconhecer os desafios inerentes deste processo. Revelaram fragilidades nas relações entre os profissionais da área de odontologia e os demais membros da ESF, marcado por sentimento de exclusão e desinteresse em participar.

Palavras-chave: Equipe de Assistência ao Paciente; Estratégia Saúde da Família; Pessoal de Saúde.

\section{REsumen}

Objetivo: Aprehender las percepciones y vivencias de los profesionales a respecto al trabajo en equipo en la Estrategia Salud de la Familia (ESF) en un municipio de mediano porte en el sur de Brasil. Método: Investigación descriptiva de naturaleza cualitativa, realizada entre abril y julio de 2016 con 13 profesionales (enfermeros, médicos, dentistas, agentes comunitarios de salud, técnicos de enfermería y auxiliar de salud bucal) actuantes en equipos de la ESF de un municipio en el sur de Brasil. Los datos fueron recolectados por intermedio de entrevistas semiestructuradas, posteriormente transcritas y sometidas al Análisis de Contenido. Resultados: Del análisis surgieron tres categorías temáticas: El trabajo en equipo en la perspectiva de los profesionales de la ESF; Estrategias para el mantenimiento del trabajo en equipo sin cotidianidad; y Percalços de la inserción de la Salud Bucal en la ESF. Conclusiones e implicaciones para una práctica: Los participantes demostraron percibir la importancia del trabajo en equipo y de la relación interpersonal, y reconocer los desafíos inherentes de este proceso. Se revelaron fragilidades en las relaciones entre los profesionales del área de odontología y los demás miembros de la ESF, marcado por sentimiento de exclusión y desinterés en participar.

Palabras clave: Grupo de Atención al Paciente; Estrategia Salud de la Familia; Personal de Salud. 


\section{INTRODUCTION}

In Brazil, the Family Health Program (FHP) was created in 1994, and aimed to promote equity on health caare and combating inequalities on service access. In virtude of it's potential to restructure Primary Care and construction of new work processes, in 1997, it started to be identified as Family Health Strategy (FHS). ${ }^{1}$

FHS promoted innovation and profound chnage on primary care organization, due to mainly the inclusion of Health Community Agents (HCA) and multiprofessional teams' work, as well as enabling to know and act about main social determinants of health of the resident population in it's comprehensiveness area. $^{2}$

The proposed model for FHS is constituted by multiprofessional teams composed by general and specialized nurse and physician in family health, nursing technician, HCA and oral health professionals (general dentist, oral health technician and/or assistant). ${ }^{2}$ These professionals have as fundamental foundation it's work, the principals of integrality and multidisciplinarity, one of the main mishaps for primary care, since the non-incorporation of actions together results in a fragmented healthcare centered on the disease and not on the individual. Beyond that, professionals' training can constitute a barrier to the team's good development of the work as undergraduate programs not always prepare students to develop skills of interaction with other professionals. ${ }^{3}$

It's important to highlight that in 2008, with the aim of amplifying primary health care resolutiveness other professionals were inserted in this context, through the Family Health Support Center (FHSC). It is constituted by professionals of different areas of knowledge (physical education, physiotherapist, speech therapist, nutritionist, occupational therapist, among others) that work on articulating FHS/primary care and initiatives such as street clinic and river area's teams. ${ }^{2}$

FHS team is multiprofessional because it's composed by different professionals working in the same work place. They are also interprofessional, mainly because there is the interaction between different professionals' work, in order to potentialize team results. ${ }^{4,5}$ These aspects are employed in health services specially on primary care, aiming to guarantee quality of care through integrality and continuity of care..$^{5}$

As in the national context, internationally the characteristics of teamwork in relation to interpersonal relationships are also already being discussed, including in the different contexts of health care. ${ }^{6}$ The concept of team is understood as an experience that is not restricted to only a group of individuals, consequently can not be understood as inflexible identity. The term team comes from the collective, or multiplicity of concepts in transformation, which is characterized by a network of connections, whereby health production processes take place. ${ }^{4}$
In order to consolidate the practices based on teamwork, and for them to enjoy mutual cooperation in harmony, it is necessary to interact, communicate and be able to put oneself in the place of the other, understanding the different knowledges in each one of its members. ${ }^{7}$

However, in the context of health, some obstacles may interfere in a negative way in the performance of integrated work, such as: uncooperative professionals, rigidly hierarchical organizational structures, social inequality among the members of the team and the high turnover of professionals in the services. ${ }^{8}$ In addition to contributing to the emergence of difficulties related to human resources, other factors may also interfere with the assistance offered to the community, such as quantifying professionals who are poor and unskilled labor. ${ }^{8}$

A review study points that the team as a social resevoir of health resources, because it has tools to create and recreate possibilities of action, from an active listening, opinion exchange and respect to new ideas. ${ }^{9}$ Team work, therefore, contributes for an important strategy to articulate health actions, integrate change agents, overcome knolwedge gap and democratize corporative relationships. In this sense, it constitutes a unique instrument to reach care improvement offered to the individual and consequently reach better therapeutic results. ${ }^{9}$

Fragility in interpersonal relationships in team work on FHS, is in consonance with the guideline of Humanize SUS that preconizes amplification of dialogue among professionals and promotion of participative administration on qualification of healht care. Thus, the existence of personal conflicts are the main drivers for not doing teamwork. These can be associated to individualism, lack of cooperation, commitment, respect and coresponsabilization. On the other hand, the maintenance of healthy interpersonal relationships in the workplace can be facilitated by open and transparent dialogue, respect and trust among members, spaces for discussion of ideas through team meetings, conflict management and, above all, valorization of teamwork. ${ }^{10}$

The need to subsidize and equip the FHS teams in the implementation/implementation of their work process, mainly due to the changes in primary health care, justifies studies with this approach. Thus, considering the relevance of discussing specific aspects of this scenario, the objective of this study was to apprehend the professionals' perceptions and experiences regarding teamwork at FHS in a medium-sized municipality in southern Brazil.

\section{METHOD}

It is a qualitative study developed in a medium-sized municipality located in the northwest of the state of Paraná, southern Brazil. This counted, on the time of the study, with a population of 403.000 inhabitants, 34 Primary Health Care 
Units (PHCU), being two rural, $74 \mathrm{FHS}$ teams and 20 oral health teams. It is highlighted that $\mathrm{PHCU}$ of the municipalities counted with FHS team, which is, at least theoretically, the entrance door for the municipality health system. It is highlighted that $63,3 \%$ of population was covered by FHS and $26,5 \%$ by oral health. ${ }^{11}$

Study informantss were FHS professionals selected by convenience among those that had participated in the quantitative step of a matrix study about "Team's atmosphere" developed with 458 professionals working in $72 \mathrm{FHS}$ teams, which the only inclusion criteria was to be inserted in teams for at least four months.

13 professionals working in different $\mathrm{FHS}$ teams participated in this study. Inclusion criteria used was the fact that even on a previous step, verbally manifested the interest in the theme and disposition/disponibility to approach experiences related to the daily experience related to working as a team deeper. It was also inclusion criteria to not belong to the same team as another professional already included in the study. Exclusion criteria adopted was the canceling or impossibility, after three tries, to make schedules compatible.

Data were collected between April and July 2016, through semistructured interview, guided by the following research question: "talk about the characteristics of team work in the FHS". It was also used the following support questions: how do you perceive/evaluate your collaboration/integration with the other team members? How do you perceive/evaluate the participation of other team members? Which aspects challenge/ favour collaboration in your teah? And Which strategies should be used to reach high integration and collaboration in your team?

Interviews were previously scheduled according to what was stabilished by participants, developed in a private envirornment at FHS - all by the responsible researcher - they lasted between 20 and 60 minutes and after authorization, they were recorded in digital media. Searching new participants occured until the sample was composed by representatives of all category constituents of FHS teams and statements of new participants didn't aggregate additional elements to higher comprehension of the study's object.

For analysis, all interviews were fully transcribed, preferably at the same day they were done, preserving participants' own language. Subsequently, the material produced was submitted to content analysis, thematic modality ${ }^{12}$ following three proposed stages:: pre-analysis, material exploration and treatment of results with inferences and interpretations. In this way, after transcribing and organizing all empirical material, the reading process was started, first floating and then minutely, to identify the general elements that made up each set of data (interview).Subsequently, data were grouped by similarity, originating three identified thematic categories and that answer the study's aim. They are: Team work on the perspective of FHS professionals; strategies to mantain team work in daily experience; and Maceration of inclusion of Oral Health in FHS.
Research followed ethical recommendations in force on Resolution 446/12 of National Concil of Health and it's project was approved by the Ethical Commitee in Research involving Human Beings from Federal University of Maringá, with protocol number 1.349.738. All participants signed a Free Consent Form in two copies. To preserve anonymity, their report quotes were identified by the letter "E" of interviewee, followed by the number indicating the order of interview and abbreviation of professional category.

\section{RESULTS}

Of 13 participants of the study, five were nurses, two physicians, two dentists, two $\mathrm{CHA}$, one nursing assistant and one oral health assistant, being eight female. Age of interviewees varied from 22 to 58 years old and time of work in current FHS team was from four months to 12 years.

\section{Teamwork in the perspective of FHS professionals}

In this category, the professionals' perceptions regarding concepts, facilitating aspects and obstacles of teamwork at the FHS are addressed. It consisted of two subcategories: Teamwork and idealized aspects by different professionals and Teamwork is not an easy task: obstacles in interpersonal relationships.

\section{Teamwork and idealized aspects by different professionals}

In this subcategory, questions were addressed as concepts and perceptions of the professionals on aspects facilitating teamwork, as well as behaviors and roles of the members that make up the FHS teams.

Teamwork has to have open and direct communication, honesty, closeness, collaboration Not always ideas will converge, but in the moment that there are divergence of ideas we can always point out to balance which is the best idea and then have consensus. We always have to listen to everybody, have to work in the same direction. (E3-Nur)

First look at the team as if it were an extension of your family! We spend a lot of time together, we can not cling to "nitpicking"! We are different, each one has its characteristics, but we have to have understanding, love! (E7-Phys)

In addition to the issues expressed in the excerpts above, respondents also reported that teamwork is closely related to cooperativism and unity in performing tasks, so the team always shares common goals and seeks to fulfill goals with respect, exchange of knowledge, and tolerance.

Each one in his assignment to a common good! This is teamwork.! (E7-Phys) 
It was also evidenced that the participants recognize the nurse as the leader of the team, which is justified by the fact that it is the professional who plans the activities and coordinates the actions, as well as being a conciliator and keeper of the information.

I see great leadership in the nurse. She has a capacity for organization, has a long-term vision. So just try to get a better view and we often go for her ideas. (E4-Phy)

The importance of the CHA role was also evident in the interviewees' speeches, as they believe that they are responsible for establishing the link between the community and the FHS team. This is because they have access to the family environment and are able to identify more easily the existing problems influencing the characterization of demand.

$\mathrm{CHA}$ are our eyes indeed, because we leave little to the community, who goes out every day is them! [...]They enter people's homes and see the problem closely! (E12-Nur)

One day a CHA passed in the house of a family and thought the baby was strange, she asked the mother to bring the child here! When the child arrived he had a heart rate of $200 \mathrm{bpm}$, and a respiratory rate of almost 100. We called SAMU and the child was taken to the hospital and then had heart surgery. CHA did not know what was happening, but she at least identified that something different was happening and convinced her mother to come! If she had no bond with this mother, this mother would probably not come.! (E11-Nur)

Most of the interviewees reported having committed to the other members of their teams, so they believe there is partnership, mutual help, respect, complicity, effort and good relationship, which is elucidated in the following statements:

I see my team very participatory, especially in group activities, partnership. The team members cooperate with each other and if one can not come, the other comes. One helps the other when needed. Everyone knows what they have to do, and if someone realizes that the other is not handling everything, one helps. (E2-CHA)

Thank God we have a very good bonding! And what works for this is respect! Respect, humility and knowing how to listen! (E12-Nur)

\section{Teamwork is not an easy task: obstacles in interpersonal relationships}

Despite the speeches that refer to the harmony between the FHS teams, difficulties also arose in the context of interpersonal relations during the work process, characterized by the presence of conflicts, estrangement and resistance to the inclusion of new professionals.

The following quote demonstrates the difficulty experienced by one of the dentistry professionals in feeling inserted for teamwork:

\begin{abstract}
I find it difficult to work as a team! Because many times we will make a suggestion, a questioning or even a criticism. People can not understand! [...]Look, I do not have much involvement with the team! It's only been a couple of weeks since Istarted attending team meetings! (E8-Den)
\end{abstract}

In the following quote, the nurse also reports her difficulty in feeling a member of the team, which is justified by the fact that she is new to the unit and is experiencing the insertion process, as well as being much younger than the other team members:

\section{I, as I am new and do not have much experience, I try to "fit in", I try to collaborate. I do not dislike them to have a good working climate. I do not know if one thing that makes it difficult is because I' $m$ very young, because they keep saying: Oh my God, a child here!" (E1-Nur)}

In general, the participants believe that what makes team members' collaboration difficult is the existence of conflicting and distant relationships, personality problems, overwork and scarcity of resources, as well as devaluation and demotivation of professionals.

One of difficulties is the excess of work, which have make people stressed! The day-to-day wear end up stressing the professionals a lot! The work increases, but the professionals do not! Sometimes a new job ends up and the conflicts begin! (E11-Enf)

On my team, there's not a very good atmosphere. The Nursing assistant doesn't get along with the CHAs. It is a veiled conflict, you realize that it is happening, but it has no way to interfere directly, you have to get around. Sometimes I want to do something and the CHAs say: "if she goes I won't go"! Then they stand on one side and the rest of the team on another. (E1-Nur)

I think one factor that makes it very difficult is arrogance, because I think that because I am graduated, I am better, that your opinion will never be valid. This ends sabotaging the team, becomes a professional sending other professionals. I think this kind of authoritarianism destroys the family health team. (E4-Phys)

The physician is very distant. His commitment is not $100 \%$ ! And this makes our work difficult! He is not interested in team's stuff, if there's a meeting, ok, it 
there is not amem! Sometimes we ask questions to other teams' physicians or with the nurse. Everybody needs to participate! The team needs him! (E6-CHA)

\section{Strategies to mantain teamwork in daily experience}

In this second category FHS professionals reported some strategies used by teams to achieve greater integration among their members and, consequently, a more harmonious work environment. The professionals were unanimous in considering the team meetings as an important strategy for the closer relationship between the members of the FHS teams and for their better performance and planning.

Team meeting is essential, in the week we don't have it it seems things don't work! Because it's there we plan for the week, month! In the face of this conversation we will get together, even discuss team problems, relationship problems! (E12-Nur)

We didn't have team meetings, it started it's been three months. Before, many times I used to pass a case to the nurse in the hallway, with her asking if it was going to take long. So you do not have the courage to take other cases. Already tried to solve myself, not everything. Because nobody wanted to hear. Now the meeting is weekly. It's getting better. I realize that you are breaking barriers, the $\mathrm{CHAs}$ are breaking that of my micro and micro. (E6-CHA)

Another strategic alternative pointed out in the speeches was to enable team members to know the work of each professional with greater ownership, so that everyone can know the difficulties that the other finds from their daily responsibilities.

I think one should know more about the other's function, to understand. So I do not know if it would be viable; but for example, in a month I stay in another micro area, so I understand a little of her difficulty. Of course, dealing with the nurse and the doctor would be very difficult. But at least follow a nurse's day to see her whole routine to understand. Everybody thinks that for the doctor make more money he does not have difficulty, and it is not quite like this. (E2-CHA)

Participants also reported that informal meetings or conversations outside or even in the work environment contribute to greater integration among team members, as can be seen in the following statements:

It's a team that pretty much lunches together every day! And the fact that we have lunch together makes the difference! It's a time you can talk, quiet, not focused on work! (E10-Den)
We always make celebrations, we give birthday gift among the team, we meet every year with only team fraternization, secret friend. In relation to the coexistence we never had problem. (E2-CHA)

\section{Maceration of inclusion of oral health in the family health strategy}

In the third category, professionals, especially dentists, reported on the relationships between the oral health team and the other members, highlighting issues such as feelings of exclusion and non-involvement.

We, from odontology, are not very integrated with the rest of the team! Sometimes I feel we are excluded, because sometimes there is a team meeting and we don't know, they say we don't have to participate, that it's not up to us to know some things, or that we don't need to get involved. (E8-Den)

Our participation in oral health is even more distant! If I do not go back when I have a home visit, I do not know! If I want to visit, I have to go the day the doctor goes.! (E10-Den)

The quotes above evidenced the feeling of exclusion experienced by dentists participants in relation to activities developed by the FHS team. However, it's important to highlight that other professionals refered to this relationship as participative and effective, as identified in the following:

Oral health is very participative here, they participate in team meetings, which are weekly, giving some contribution share, speaking about some theme! (E11-Nur)

On $\mathrm{PHCU}$, oral health in general, has a private and climatized envirornment to develop their activities, where there is not the circulation of patients or even team members, which ends up restricting the contact. However, for them, the physical space doesn't influence the integration with the team in a negative way.

I think that the physical space does not disturb the interaction! (E9-OH.Assist)

Everyone says that we are isolated because we are in a place apart! But I think that does not interfere, because if they need them come here and talk to me! (E10-Den)

What has been observed through the speeches is that the exclusion is more related to the relationships and roles within the team, so that sometimes the other members end up excluding oral health from the activities of the ESF because they think that not all issues of everyday life are of interest to them. 
We do not have much contact with the odontology, but they are essential. They participate in some team meetings. Because there are meetings that do not need them to be. (E5-Nur.Assist)

I see fellow nurses who exclude, then say that the odontology is excluded, but it was he who excluded. (E11-Nur)

Although dentists face challenges stemming from fragmented training, they believe that the nurse, as a leader in the team, must involve them in the activities, in search of greater interaction between them and the team.

The team involvement depends a lot on the nurse, because she is the team leader; then, in my opinion, it's up to her to be calling us more to participate, discuss the cases and to involve us. (E8-Den)

When oral health is away from the rest of the team I see it as a leadership issue! The role of the nurse in the team is leadership, so it will depend on you if you give space! (E11-Enf)

\section{DISCUSSION}

For teamwork to happen, there is a need for collaboration among its members, exchange between different knowledge and complementarity in activities, as reported by the participants of this study. It also presupposes relationships that promote collaboration and communication in order to contribute to the development of the work, guiding in the dialogical and horizontalized relations. ${ }^{13}$ This interprofessional and multiprofessional collaboration characterizes important aspect in the accomplishment of improvements in the quality of the assistance offered to the patients. ${ }^{14}$

In this sense, the possibility of adding different knowledge to provide assistance to the needs of the population is one of the main assumptions of the FHS. In the processes of management of health promotion and prevention, it is expected that professionals involved in the model proposed by primary care will think about strategies together, with participation and involvement of all its members. Therefore, in order for the results to be achieved it is essential to have continuous dialogue and contact between the teams. ${ }^{15}$

In general, the health team recognizes the nurse as mediator and leader, an important element in the relationships and interactions of professionals with the community. At the FHS, nurses still work in the management of the health unit, maintaining good working relationships and conflict management, managing the flow of information, assigning responsibilities and directing staff activities. ${ }^{16,17}$ Teaching-learning, resource management, communication, teamwork, integrated management of processes, decision making, flexibility, creativity, customer focus, knowledge acquisition, commitment, entrepreneurship, leadership, negotiation and strategic vision are known as nurse's administration competences. ${ }^{18}$

Because they play a leading role in the FHS, nurses should value this position and emphasize it with the teams. This can occur through effective dialogue, exchange of information, good relationship in teamwork, integration among members, recognition of limitations and stimulation of the individual potential of each professional. ${ }^{15,19} \mathrm{In}$ this way and having the nurse as mediator, the team can achieve greater harmony in the work, as well as collaboration and participation of all its members. It should be pointed out that the $\mathrm{CHA}$ constitute the largest portion of professionals that are part of the FHS teams and carry out important activities to carry out their action plan. It is the member that plays a mediating role between the health team and the community, since at the same time that it resides in the area of action, it is also part of the health team. In this sense, the $\mathrm{CHA}$ generally knows and lives the demands brought by the residents, accompanies the families of their community, intervenes in educational processes, provides information, facilitates the users' access to the health unit, performs actions of small complexity and enables entry of the health professional in the people's homes. ${ }^{19-21}$ Information sharing and integration with other members are essential for the development of teamwork, as highlighted by the professionals under study.

As it was observed in the report of one of the nurses, the ACSs do not have technical knowledge, however they feed on technical-scientific knowledge acquired through team experiences and popular knowledge embedded in the local health culture. ${ }^{21}$ In this way, one of the inherent competences of the $\mathrm{CHA}$ work is the ability to overcome the dichotomy between technical knowledge and popular knowledge, with the intention of promoting discourses that provide the widening of different understandings and experiences of the concept of health. ${ }^{22}$

In order to maintain the interaction and cooperation between the ESF team members, it is worth mentioning that, as discussed by the participants, dialogue and listening are important tools for creating the link between the participants and consequently contribute to teamwork more effective. The respect and appreciation of the professional are also essential, either by the member or by the managers and users. In this sense, teams that are able to bring these aspects together can certainly strengthen the bonds between their members and, therefore, establish healthier interpersonal relationships in the work environment. ${ }^{23}$

Sometimes the functions performed by team members are not clear to all, but rather constrained and confusing due to the established functioning of the team and the PHCU. It is emphasized that once each one becomes aware of the work of the other and an understanding of the importance of each member insertion into the team, the roles and functions become clearer for all professionals and the work process flows better. ${ }^{13}$ 
Even though the proposal is structured from the health attention model, unfortunately the work in health services contexts as Unique Health System (SUS), can face numerous challenges to ensure quality assistance to users, among them the lack of ethics, respect and solidarity in the relationships among health professionals. Aspects that can provide a conflicted, unmotivated work environment that does not include teamwork. ${ }^{24}$

In addition, other aspects can also interfere in the harmony and cooperation between team professionals. As reported by one of the nurses, the age of the professional and the time of actuation, for example, exert influence in how they perceive the work in their teams. In other words, workers up to 30 years of age or up to a year of performance in the FHS tend to have a less positive perspective on the development of teamwork than older and longer working professionals. This is mainly due to the fact that they are experiencing the process of insertion in the team, which involves acceptance by the others and appropriate appropriation of the work routine..$^{25}$

It was notorious on participants' quotes how much interactions between members interfere on team's development. Hence the importance of building common projects in order to encourage complementarity between the specialized activities of the different team professionals as well as the interaction and cooperation between them. ${ }^{26}$

Study's results corroborate with the literature by identifying that periodic meetings are an important integration and planning strategy, especially for health planning, from the multiprofessional team that has different knowledge and skills. It provides space for reflection and problem solving, inside and outside the teams, elaboration of goals, clarification, besides being a tool that brings together team professionals. ${ }^{23}$

As inferred by the participants in this study, the use of collective strategies that aim at sociability, such as parties and celebrations, sometimes provide a more informal work environment, strengthen ties and interpersonal relationships, as it is at these moments that the ties of friendship and trust are established more easily. Consequently, there is relief from work tensions, which can minimize the stressful effects inherent in professional practice, as well as provide the affective bonds between team members. ${ }^{27}$

It was also evident in the participants' speeches that oral health professionals experience important mishaps in the development of their activities as members of the FHS teams. Although there have been advances arising from the insertion of oral health in the FHS teams, there is still difficulty in inserting these professionals into the various activities that are routinely performed in this assistance area.

This occurs both on the part of oral health professionals and other members of the FHS, influencing the incorporation of their basic precepts, such as teamwork and valuing the family/household as the locus of care. This problematic may be associated with the historically and socially constructed culture in private practices, with the development of mechanized activities, and the difficulty/willingness of these professionals to work as a team and to incorporate practices related to primary care, such as home visits. ${ }^{28}$

Thus, the inclusion of oral health in the FHS began in 2001, with the purpose of offering dental care to all regions of the country. The main objective was to give continuity to the family-centered axis, with a view to implementing a care mode that could minimize the epidemiological indices of oral health in the country, in addition to increasing access for the entire population. ${ }^{29}$

The inclusion of the dental professional in the FHS confronts his traditional formation of fragmented knowledge, common among other health professionals and represents a challenge for multiprofessional work. When these professionals have continuous training in the context of collective health and the family, they are able to establish parallels with greater ease regarding integration in teamwork, understanding from interprofessional work and the valuation of common professional and collaborative skills. ${ }^{30}$ However, involving them in healthcare practices developed by the FHS requires joint action of all those involved, either the managers or the members of the teams, especially the nurse who has a leadership role and is responsible for the teamwork.

\section{CONCLUSIONS AND IMPLICATIONS FOR PRACTICE}

FHS professionals face several challenges to develop teamwork, mainly on interpersonal relationships, with the presence of complict and distancing among members. Dealing with different views, culture, beliefs and personalities is no easy task. Added to this are the changes that have occurred in Primary Health Care, such as the incorporation of the oral health team. These challenges can be overcome through the incorporation of diverse strategies, such as: holding periodic meetings of the team, knowledge and appreciation of the role of each one of its members and stimulating closer ties between professionals, in addition to the work environment. Results show that FHS professionals perceive the importance of teamwork in the current model of primary care, and that some aspects, such as communication, active listening and respect to the particularities of each profession, are essential for maintaining harmony and implementation of a collaborative practice. It was also evidenced that the oral health team experiences feelings of exclusion and the team, which does not always recognize the importance of their work in the FHS. It is noteworthy that in the perception of these professionals the inclusion/exclusion may be related to the nurse's posture, since it is the one that usually controls the activities of the team. 
This result in itself points to the need for greater attention by managers and team members regarding the insertion of oral health in the FHT, as well as the development of mechanisms that reinforce the interaction and integration among its members. has the purpose of adding value and expanding the services provided by the teams to the community. In addition, it can also stimulate reflection on the work process of these professionals, whether in the short or long term, in order to provide improvements in the working relationships and, consequently, in the quality of care offered to the community.

Finally, a possible limitation of the study may be related to the number of participants in each professional category and/ or the place where the data were collected. This is because, because they are in the work environment and fear to expose other team members, participants may have been embarrassed to report aspects of the corporate process and/or interpersonal relationships involved, which may have some implication in the results found.

\section{REFERENCES}

1. Silva LA, Casotti CA, Chaves SCL. A produção científica brasileira sobre a Estratégia Saúde da Família e a mudança no modelo de atenção. Ciênc Saúde Coletiva [Internet]. 2013; [cited 2016 Nov 10]; 18(1):22132. Available from: http://www.scielo.br/pdf/csc/v18n1/23.pdf

2. Ministério da Saúde (BR). Portaria №. 2488, de 21 de outubro de 2011. Aprova a Política Nacional de Atenção Básica, estabelecendo a revisão de diretrizes e normas para a organização da Atenção Básica, para a Estratégia Saúde da família (ESF) e o Programa Agentes Comunitários de Saúde (PACS). Brasília (DF): Ministério da Saúde; 2011.

3. Silva JAM, Peduzzi M, Orchard C, Leonello VM. Educação interprofissional e prática colaborativa na Atenção Primária à Saúde. Rev Esc Enferm USP [Internet]. 2015; [cited 2018 Mar 6]; 49(no.esp2):16-24. Available from: http://www.scielo.br/pdf/reeusp/v49nspe2/1980-220Xreeusp-49-spe2-0016.pdf

4. Peduzzi M, Carvalho BG, Mandú ENT, Souza GC, Silva JAM. Trabalho em equipe sob a perspectiva interprofissional. Proenf Gestão. 2012;1(3):9-39.

5. Gelbcke FL, Matos E, Sallum NC. Desafios para a integração multiprofissional e interdisciplinar. Rev Temp Actas Saúde Coletiva [Internet]. 2012; [cited 2017 Mar 6]; 6(4):31-9. Available from: http:// tempusactas.unb.br/index.php/tempus/article/view/1202/1087

6. West MA, Lyubovikova J. Illusion softeans working in healthcare. J Health Organ Manag. 2013;27(1):134-42.

7. Duarte MLC, Boeck JN. O trabalho em equipe na enfermagem e os limites e possibilidades da estratégia saúde da família. Trab Educ Saúde [Internet]. 2015 Sep/Dec; [cited 2017 Mar 6]; 13(3):709-20. Available from: http://www.scielo.br/pdf/tes/v13n3/1981-7746-tes-13-03-0709. pdf

8. Uchôa AC, Vieira RMV, Rocha PM, Rocha NSD, Maroto RM. Trabalho em equipe no contexto da reabilitação infantil. Physis Rev Saúde Coletiva [Internet]. 2012; [cited 2017 Mar 10];22(1):385-400. Available from: http://www.scielo.br/pdf/physis/v22n1/v22n1a21.pdf

9. Camelo $\mathrm{SHH}$. O trabalho em equipe na instituição hospitalar: uma revisão integrativa. Cogitare Enferm [Internet]. 2011 Oct/Dec; [cited 2018 Mar 6]; 16(4):734-40. Available from: https://revistas.ufpr.br/ cogitare/article/view/19977/17068
10. Fernandes HN, Thofehrn MB, Porto AR, Amestoy SC, Jacondino MB Soares MR. Interpersonal relationships in work of multiprofessional team of family health unit. Rev Pesq Cuid Fundam Online [Internet] 2015 Jan/Mar; [cited 2018 Mar 6]; 7(1):1915-26. Available from https://www.ssoar.info/ssoar/bitstream/handle/document/54324/ssoarrevpesquisa-2015-1-fernandes_et_al-Interpersonal_relationships_in work_of.pdf?sequence=1

11. Ministério da Saúde (BR). Departamento de Atenção Básica. 2018 [citado 2018 mar 10]. Cobertura da Atenção Básica. Available from: https://egestorab.saude.gov.br/paginas/acessoPublico/relatorios/ relHistoricoCoberturaAB.xhtml

12. Bardin L. Análise de conteúdo. São Paulo: Edições 70; 2011.

13. Silva SEM, Moreira MCN. Equipe de saúde: negociações e limites da autonomia, pertencimento e reconhecimento do outro. Ciênc Saúde Coletiva [Internet]. 2015; [cited 2018 Mar 3];20(10):3033-42. Available from: http://www.scielo.br/pdf/csc/v20n10/1413-8123-csc-20-10-3033. pdf

14. Morgan S, Pullon S, McKinlay E. Observation of interprofessional collaborative practice in primary care teams: an integrative literature review. Int J Nurs Stud. 2015;52(7):1217-30.

15. Cervinski LF, Neumann AP, Cardoso C, Biasus F. O trabalho em equipe na estratégia de saúde da família: desafios e possibilidades. Perspectiva [Internet]. 2012 Dec; [cited 2017 Mar 3]; 36(136):111-22. Available from: http://www.uricer.edu.br/site/pdfs/perspectiva/136_312.pdf

16. Lanzoni GMM, Meirelles BHS. Liderança do enfermeiro: elemento interveniente na rede de relações do agente comunitário de saúde. Rev Bras Enferm [Internet]. 2013 Jul/Aug; [cited 2017 Mar 3]; 66(4):557-63. Available from: http://www.scielo.br/pdf/reben/v66n4/v66n4a14.pdf

17. Costa EMS, Peres AM, Bernardino E, Sade PMC. Estilos de liderança dos enfermeiros que atuam na estratégia de saúde da família. Ciênc Cuid Saúde [Internet]. 2015 Jan/Mar; [cited 2017 mar 5]; 14(1):9629. Available from: http://www.periodicos.uem.br/ojs/index.php/ CiencCuidSaude/article/view/20756

18. Balsanelli AP, Cunha ICKO, Feldman LB, Ruthes RM, organizadoras Competências gerenciais: desafios para o enfermeiro. São Paulo: Martinari; 2008.

19. Souza RB, Ilha S, Lima CLS, Gracioli MAS, Backes DS, Nicola GDO Organização e liderança no trabalho do enfermeiro: percepção de enfermeiros e técnicos de enfermagem. Rev Enferm Cent Oeste Min [Internet]. 2013 May/Aug; [cited 2017 Mar 5]; 3(2):687-95. Available from: http://www.seer.ufsj.edu.br/index.php/recom/article/view/360

20. Machado LM, Mattos KM, Colomé JS, Freitas NQ, Sangoi TP. Estratégia saúde da família: a percepção do agente comunitário de saúde quanto a sua atuação. Ciênc Cuid Saúde [Internet]. 2015 Apr/Jun; [cited 2017 Mar 10]; 14(2):1105-12. Available from: http://www.periodicos.uem.br/ ojs/index.php/CiencCuidSaude/article/view/22612

21. Maciazeki-Gomes RC, Souza CD, Baggio L, Wachs F. O trabalho do agente comunitário de saúde na perspectiva da educação popular em saúde: possibilidades e desafios. Ciênc saúde Coletiva [Internet] 2016; [cited 2017 Mar 10]; 21(5):1637-46. Available from: http://www. scielo.br/pdf/csc/v21n5/1413-8123-csc-21-05-1637.pdf

22. Pinto RM, da Silva SB, Soriano R. Community Health Workers in Brazil's Unified Health System: a framework of their praxis and contributions to patient health behaviors. Soc Sci Med. 2012;74(6):940-7.

23. Lima FS, Amestoy SC, Jacondino MB, Trindade LM, Silva CN, Fuculo Junior PRB. Exercício da liderança do enfermeiro na estratégia saúde da família. Rev Pesqui Cuid Fundam (Online) [Internet]. 2016; Jan/Mar; [cited 2017 Mar 10]; 8(1):3893-906. Available from: http://pesquisa. bvsalud.org/portal/resource/pt/bde-27363

24. Sá MC, Azevedo CS. Subjetividade e Gestão: explorando articulações psicossociais no trabalho gerencial e no trabalho em saúde. In Azevedo CS, Sá MC, org. Subjetividade, Gestão e Cuidado em Saúde: abordagens da psicossociologia. Rio de Janeiro (RJ): Editora Fiocruz; 2013. p. 33-50. 
25. Peruzzo HE, Silva ES, Haddad MCFL, Marcon SS. Influência do sexo, idade e tempo de atuação na percepção sobre o trabalho em equipe. Rev Min Enferm [Internet]. 2017; [cited 2017 Dec 10]; 21:e-1011. Available from: http://www.reme.org.br/artigo/detalhes/1147

26. Garcia ACP, Lima RCD, Freitas PSS, Fachetti T, Andrade MAC. O trabalho em equipe na estratégia saúde da família. Rev Epidemiol Control Infect [Internet]. 2015; [cited 2017 Jan 10]; 5(1):31-6. Available from: https://online.unisc.br/seer/index.php/epidemiologia/article/ viewFile/5314/4127

27. Martins JT, Robazzi MLCC. Estratégias defensivas utilizadas por enfermeiros de unidade de terapia intensiva: Reflexão na ótica dejouriana. Ciênc Cuid Saúde [Internet]. 2012; [cited 2017 Jan 10]; 11:34-41. Available from: http://periodicos.uem.br/ojs/index.php/ CiencCuidSaude/article/view/5071
28. Giudice ACMP, Pezzato LM, Botazzo C. Práticas avaliativas: reflexões acerca da inserção da saúde bucal na Equipe de Saúde da Família. Saúde Debate [Internet]. 2013 Jan/Mar; [cited 2017 Jul 10]; 37(96):3242. Available from: http://www.scielo.br/pdf/sdeb/v37n96/05.pdf

29. Ministério da Saúde (BR). Programa Saúde da Família. Equipes de Saúde Bucal: projetos, programas e relatórios. Brasília (DF): Ministério da Saúde; 2002.

30. Padula MGC, Aguilar-da-Silva RH. Professional profile of dentists who are members of the Family Health Strategy city of Marília, São Paulo: the challenge of interprofessional work. Rev Odontol UNESP [Internet]. 2014; [cited 2017 Jul 11]; 43(1):52-60. Available from: http://www.scielo. br/pdf/rounesp/v43n1/1807-2577-rounesp-43-01-00052.pdf 